\title{
Effect of Planting Systems and Foliar Application of Iron and Silicon on Growth and Yield of Rice (Oryza sativa L.)
}

\author{
Gangadi Kalyan Reddy*, C. Umesha and Thomas Abraham \\ Department of Agronomy, Sam Higginbottom University of Agriculture, Technology and \\ Sciences, Prayagraj, Uttar Pradesh, India \\ *Corresponding author
}

\section{A B S T R A C T}

\section{Keywords}

Rice, Planting systems, Foliar application, Iron, silicon, Growth, Yield

Article Info

Accepted: 07 October 2020 Available Online: 10 November 2020

\begin{abstract}
A field experiment was conducted during Kharif season of 2019 at Department of Agronomy in Crop Research Farm, Sam Higginbottom University of Agriculture, Technology and Sciences, Prayagraj, Uttar Pradesh, India. The objective was to study effect of planting systems and foliar application of iron and silicon on growth and yield of rice (Oryza sativa L.) Var. Shiats Dhan- 1 under Randomized block design comprising of 3 replications and 10 treatments (Conventional Transplanting of Rice, System of Rice Intensification, Iron at $0.5 \%, 1.0 \%$ and Silicon at $0.5 \%, 1.0 \%$ respectively). The experimental results revealed that with $\mathrm{T}_{10}\left(\mathrm{SRI}+1.0 \% \mathrm{FA}\right.$ of $\mathrm{FeSO}_{4}+1.0 \% \mathrm{FA}$ of $\mathrm{Na}_{2} \mathrm{SiO}_{3}$ ) recorded highest number of tillers/hill (20.07), dry weight (112.40 g), effective tillera/hill (19.20), number of grains/panicle (283.92), grain yield (6.08 t/ha), straw yield $(9.31 \mathrm{t} / \mathrm{ha})$ and harvest index $(39.50 \%)$. Maximum plant height $(113.87 \mathrm{~cm})$ was recorded with $\mathrm{T}_{3}\left(\mathrm{CTR}+1.0 \% \mathrm{FA}\right.$ of $\left.\mathrm{FeSO}_{4}\right)$. Highest LAI (5.67) was recorded with $\mathrm{T}_{8}(\mathrm{SRI}+$ $1.0 \% \mathrm{FA}$ of $\left.\mathrm{FeSO}_{4}\right)$. And highest length of panicle $(23.46 \mathrm{~cm})$ was recorded with $\mathrm{T}_{9}(\mathrm{SRI}$ $+0.5 \% \mathrm{FA}$ of $\mathrm{FeSO}_{4}+0.5 \% \mathrm{FA}$ of $\mathrm{Na}_{2} \mathrm{SiO}_{3}$ ).
\end{abstract}

\section{Introduction}

Rice is a staple cereal food crop for more than half of the world's population and is generally grown by transplanting seedlings into a puddled soil in Asia. Worldwide, India stands first in rice producing area and second in production (172 million t/ha) after China of global rice production. However, the average productivity of rice in India is only $2.57 \mathrm{t} / \mathrm{ha}$ against the global average of $4.0 \mathrm{t} / \mathrm{ha}$ (FAO, 2018). Increasing productivity and production are essential to meet the food requirement of the burgeoning population. During the green revolution era, India had achieved food security owing to introduction of high-inputresponsive varieties of rice. However, it is observed that rice yields are either decelerating/ stagnating/declining in post green revolution era mainly due to imbalanced use of fertilizer, soil degradation, etc. (Prakash, 2010).

System of rice intensification (SRI) was first developed in Madagascar in 1980's. It is a combination of several practices that include slight changes in nursery management, time of transplanting and management of water, 
nutrients and weeds. Through the fundamental practices remain more or less the same, SRI emphasizes certain changes in agronomic practices from conventional rice cultivation. It was noticed that, farmers adopting conventional methods could increase their production only by using expensive inputs such as chemical fertilizers, pesticides and hybrid seeds etc. (Reddy and Shenoy, 2013).

Micronutrient deficiency is considered as one of the major causes of declining productivity trends observed in rice growing countries. Foliar application of micronutrients is a simple way for making quick correction of plant nutrient status. It boosts process responsible for potential yield of crops such as nitrogen metabolism, uptake of $\mathrm{N}$ and protein, photosynthesis-chlorophyll synthesis carbonic anhydrase activity, resistant to abiotic and biotic stress-protection against oxidative damage (Kulhare et al., 2017).

Iron plays a vital role in the formation of chlorophyll and takes part in oxidationreduction reaction involved in RNA metabolism of chloroplast. It is a constituent of enzyme ferredoxin and cytochromes and is involved in symbiotic $\mathrm{N}$ fixation in the synthesis of several metalloenzymes, carbohydrate metabolism and protein synthesis (Mishra and Mishra, 2003).Fe deficiency was considered as a possible cause for the decline in rice yield (Jolley et al., 1996). Soil application of inorganic Fe salts is ineffective in controlling Fe-deficiency except when application rates are large (Pal et al., 2008). Although in most of the studies foliar application has an edge over soil application (Rattan et al., 2008; Abadía et al., 2011).

Silicon ( $\mathrm{Si}$ ) is the second most abundant element in the earth's crust. Silicon application improves the availability of applied fertilizer nutrients (namely $\mathrm{N}, \mathrm{P}$, and
K) and offers the potential to improve their agronomic performance and efficiency in terms of yield response (Rao and Susmitha, 2017). It is a principal soil component lost during weathering and the conversions of $\mathrm{Si}$ to secondary minerals are most important mechanisms of soil formation. Due to continuous mono-cropping and/or intensive cultivation of cereal crops like rice, the soil $\mathrm{Si}$ concentration is depleted which can be the main reason for declined rice yields (Mali et al., 2008). A rice crop producing a yield of $5000 \mathrm{~kg} / \mathrm{ha}$ removes $230-470 \mathrm{~kg} / \mathrm{ha}$. In continuous cropping with high silicon accumulator species such as sugarcane, the removal of PAS can be greater than the supply via natural processes releasing it into the soil unless fertilized with silicon (Savant et al, 1997; McGinnity, 2015). The critical level of $\mathrm{Si}$ in soil is $40 \mathrm{mg} / \mathrm{kg}$ and the critical level ofSi in rice (leaf and straw) is 5\% (Rao and Susmitha, 2017). Its deficiency leads to soft and droopy leaves, reduced photosynthetic activity, reduced grain yields and number of panicles (IRRI, 2016). Reduced amounts of silicon in plants produces necrosis, disturbance in leaf photosynthetic efficiency, growth retardation and reduced grain yields in cereals especially in rice (Shashidhar et al., 2008).

\section{Materials and Methods}

A field experiment was conducted during kharif season of 2019, at Crop research farm of Department of Agronomy at Sam Higginbottom University of Agriculture, Technology, and Sciences, Prayagraj which is located at $25^{\circ} 24^{\prime} 42^{\prime \prime} \mathrm{N}$ latitude, $81^{\circ} 50^{\prime} 56^{\prime \prime} \mathrm{E}$ longitude and $98 \mathrm{~m}$ altitude above the mean sea level (MSL). To assess the effect of planting systems and foliar application of iron and silicon on growth and yield of rice (Oryza sativa $L$.). The experiment was laid out in Randomized Block Design comprising of 10 treatments which are replicated thrice. Each 
treatment net plot size is $3 \mathrm{~m} \times 3 \mathrm{~m}$. RDF of NPK was 120:60:60in all treatments and two planting systems were taken CTR and SRI along with that iron and silicon was taken at 0.5 and $1.0 \%$. Treatments were $\mathrm{T}_{1}(\mathrm{CTR}+$ Control), $\mathrm{T}_{2}\left(\mathrm{CTR}+0.5 \% \mathrm{FA}\right.$ of $\left.\mathrm{FeSO}_{4}\right)$, $\mathrm{T}_{3}\left(\mathrm{CTR}+1.0 \% \mathrm{FA}\right.$ of $\left.\mathrm{FeSO}_{4}\right), \mathrm{T}_{4}(\mathrm{CTR}+$ $0.5 \%$ FA of $\mathrm{FeSO}_{4}+0.5 \% \mathrm{FA}$ of $\mathrm{Na}_{2} \mathrm{SiO}_{3}$ ), $\mathrm{T}_{5}\left(\mathrm{CTR}+1.0 \% \mathrm{FA}\right.$ of $\mathrm{FeSO}_{4}+1.0 \% \mathrm{FA}$ of $\left.\mathrm{Na}_{2} \mathrm{SiO}_{3}\right), \mathrm{T}_{6}(\mathrm{SRI}+\mathrm{Control}), \mathrm{T}_{7}(\mathrm{SRI}+0.5 \%$ FA of $\left.\mathrm{FeSO}_{4}\right), \mathrm{T}_{8}\left(\mathrm{SRI}+1.0 \% \mathrm{FA}\right.$ of $\left.\mathrm{FeSO}_{4}\right)$, $\mathrm{T}_{9}\left(\mathrm{SRI}+0.5 \% \mathrm{FA}\right.$ of $\mathrm{FeSO}_{4}+0.5 \% \mathrm{FA}$ of $\left.\mathrm{Na}_{2} \mathrm{SiO}_{3}\right)$ and $\mathrm{T}_{10}\left(\mathrm{SRI}+1.0 \% \mathrm{FA}\right.$ of $\mathrm{FeSO}_{4}+$ $1.0 \%$ FA of $\mathrm{Na}_{2} \mathrm{SiO}_{3}$ ). In CTR 21 day old with spacing of $20 \mathrm{~cm} \mathrm{x} 15 \mathrm{~cm}$ and 2 seedlings were transplanted. In SRI single seedling with spacing of $25 \mathrm{~cm} \times 25 \mathrm{~cm}$ and 12 day old was transplanted. Iron was given as ferrous sulphate foliar application at 25 and 50 DAT. Whereas, Silicon as sodium silicate at 30 and 60 DAT. After harvesting, grains were separately from each net plot and were dried under sun for three days. Later winnowed, cleaned and weight of the grain per net plot value, the grain yield per ha was computed and expressed in tonnes per hectare. After complete drying under sun for 10 days straw yield from each net plot was recorded and expressed in tonnes per hectare. The data was computed and analysed by following statistical method of Gomez and Gomez (1984). The benefit: cost ratio was worked out after price value of grain with straw and total cost included in crop cultivation. After thorough field preparation initial soil samples were taken to analyse for available major nutrients. Nitrogen (N), phosphorous $(\mathrm{P})$, potassium $(\mathrm{K})$, Organic Carbon (OC), $\mathrm{pH}$ and soluble salts. The type of soil in experimental field is sandy clay. The $\mathrm{pH}$ of the experimental field was 7.7, EC of $0.45 \mathrm{dS} / \mathrm{m}$, organic carbon was $0.44 \%$. The $\mathrm{N}$ status of the experimental field was low (99 $\mathrm{kg} / \mathrm{ha})$, medium in available $\mathrm{P}(27 \mathrm{~kg} / \mathrm{ha})$ while available $\mathrm{K}$ status was in higher range (291.2 kg/ha). Growth parameters viz. plant height $(\mathrm{cm})$, No. of tillers/hill, dry matter accumulation $\mathrm{g} /$ hillwere recorded manually on five randomly selected representative plants from each plot of each replication separately as well as yield and yield attributing character viz. grain yield t/ha, straw yield t/ha, No. of panicles/hill, and No. of grains/panicle were recorded as per the standard method. The oxidizable organic carbon was determined by Walkley and Black (1934), $\mathrm{pH}$ by $\mathrm{pH}$ meter and ECe by electrical conductivity bridge with glass electrode in a 1:2.5 soil water suspension (Jackson 1973). Soil texture by the Bouyoucos Hydrometer Method (Gee and Baudev, 1986). Available nitrogen was determined by Subbiah and Asija (1956), Available phosphorus was determined by Olsen et al., (1954) and available potash was determined by Flame photometric method, Jackson (1973).

\section{Results and Discussion}

\section{Growth attributes}

The growth attributes of rice, viz., Plant height, number of tillers/hill, dry weight, Leaf area index were significantly influenced by both planting systems; CTR, SRI and foliar application of iron and silicon.

It is evident from Table 1 that plant height measured increased with advancement in crop growth. At harvest treatment $\mathrm{T}_{3}(\mathrm{CTR}+1.0 \%$ $\mathrm{FeSO}_{4}$ ) recorded significantly higher plant height $(113.87 \mathrm{~cm})$ which might be due to CTR planting system i.e., with decrease in row spacing increased the plant height. Similar result was also reported by Ninad et al., 2017 and Mehta et al., 2019. Foliar application of micronutrients also might be reason for increase in plant height as they accelerate the enzymatic activity and auxin metabolism in plants (Sudha and Stalin, 2015). 
Number of tillers per hill (20.07) and dry weight per hill $(112.40 \mathrm{~g})$ was recorded significantly higher with treatment $\mathrm{T}_{10}$ (SRI + $1.0 \% \mathrm{FeSO}_{4}+1.0 \% \mathrm{Na}_{2} \mathrm{SiO}_{3}$ ). Increased in shoot: root ratio and production of greater number of tillers on individual hill basis with wider spacing, younger seedlings in SRI at later growth stages was the reason for increase in dry weight and number of tillers per hill was also observed by Kumar et al., 2006; Rajesh and Thanunathan, 2003; Mohammed et al., 2016. Iron nutrition had a positive effect on tiller production of rice as also stated by Kumar et al., 2018 and dry matter production before physiological maturity of the crop by Singh and Singh. 2018. Increase in number of tillers and dry weight at physiological maturity stage. might be also due to silicon foliar application by Prakash et al., 2011 and Fallah, 2012.

Higher Leaf area index (5.67) was influenced significantly with treatment $\mathrm{T}_{8}(\mathrm{SRI}+1.0 \%$ $\mathrm{FeSO}_{4}$ ). The higher leaf area index might be due to higher number of tillers putting forth more leaves resulted higher leaf area index.SRI promoted more vigorous growth leaf area index than the conventional planting was also observed by Ali and Izhar., 2017; Zheng et al., 2004). (Mahajan and Khurana, 2014; Kumar et al., 2015) also observed similar, result of increase in LAI with foliar application of iron when compared to control.

\section{Yield attributes}

The yield attributes of rice viz., effective tillers per hill, length of panicle, number of grains per panicle, grain yield, straw yield and harvest index were significantly influenced by both planting systems; CTR, SRI and foliar application of iron and silicon.

Number of effective tillers per hill (19.20), number of grains per panicle (283.92), grain yield (6.08 t/ha), straw yield (9.31 t/ha) and harvest index $(39.50 \%)$ were recorded significantly higher with treatment $\mathrm{T}_{10}(\mathrm{SRI}+$ $\left.1.0 \% \mathrm{FeSO}_{4}+1.0 \% \quad \mathrm{Na}_{2} \mathrm{SiO}_{3}\right)$. Highest Length of panicle $(23.46 \mathrm{~cm})$ was recorded significantly with treatment $\mathrm{T}_{9}(\mathrm{SRI}+0.5 \%$ FA of $\mathrm{FeSO}_{4}+0.5 \%$ FA of $\mathrm{Na}_{2} \mathrm{SiO}_{3}$ ). And there was no significant difference was found in test weight.

The maximum number of productive tillers/hill was performed with SRI while the minimum with CTR was also reported by Anwari et al., 2019. The increase in number of effective tillers/hill might be due to foliar application of iron at maximum tillering stage was also observed by Sowmya et al., (2017). Prakash et al., (2011) and Munir et al., (2003) also observed similar results with foliar spray of silicon.

The panicle length increased significantly with the combination of iron and silicon in both planting systems. Similar, finding was also reported by Viraktamath (2006). Foliar application of iron during growth period improved chlorophyll content and photosynthesis caused increase of panicle length by Gill and Walia, 2013. silicon which depositedat cellular levels makes plant parts more elongated and erect which also might be reason for increase in panicle length. Also observed by Anand et al., (2018).

Increase in number of grains per panicle might be due to plant spacing with SRI considerably resulted in advantage of space, light and circulatory air which might resulted in increased nutrient uptake and better dry matter assimilation leading to a consequent increase in a greater number of grains/panicle by Saju et al., (2019). And also, highest number of grains/panicle also might be also due to the foliar application of both iron and silicon. The current results were agreed with the findings of Esfahan et al., (2014). 


\begin{tabular}{|c|c|c|c|c|c|}
\hline & & & \multicolumn{2}{|c|}{ Table.1 Influence of planting system, foliar application of iron and silicon on growth characters of rice } & \\
\hline & Treatment & Plant height (cm) & No. of tillers/hill & Dry weight (g/hill) & LAI \\
\hline $\mathrm{T}_{1}$ & CTR + Control & 110.60 & 10.60 & 79.07 & 3.93 \\
\hline $\mathrm{T}_{2}$ & $\mathrm{CTR}+0.5 \% \mathrm{FeSO}_{4}$ & 109.27 & 11.67 & 80.3 & 4.51 \\
\hline $\mathrm{T}_{3}$ & $\mathrm{CTR}+1.0 \% \mathrm{FeSO}_{4}$ & 113.87 & 11.60 & 83.67 & 4.31 \\
\hline $\mathrm{T}_{4}$ & $\mathrm{CTR}+0.5 \% \mathrm{FeSO}_{4}+0.5 \% \mathrm{Na}_{2} \mathrm{SiO}_{3}$ & 111.67 & 11.47 & 82.77 & 4.62 \\
\hline $\mathrm{T}_{5}$ & $\mathrm{CTR}+1.0 \% \mathrm{FeSO}_{4}+1.0 \% \mathrm{Na}_{2} \mathrm{SiO}_{3}$ & 110.27 & 11.73 & 84.63 & 4.72 \\
\hline $\mathrm{T}_{6}$ & SRI + Control & 107.43 & 18.10 & 95.63 & 4.87 \\
\hline $\mathrm{T}_{7}$ & $\mathrm{SRI}+0.5 \% \mathrm{FeSO}_{4}$ & 109.40 & 18.13 & 96.1 & 5.11 \\
\hline $\mathrm{T}_{8}$ & $\mathrm{SRI}+1.0 \% \mathrm{FeSO}_{4}$ & 110.27 & 18.87 & 96.73 & 5.67 \\
\hline $\mathrm{T}_{9}$ & $\mathrm{SRI}+0.5 \% \mathrm{FeSO}_{4}+0.5 \% \mathrm{Na}_{2} \mathrm{SiO}_{3}$ & 109.40 & 19.40 & 103.3 & 5.26 \\
\hline $\mathrm{T}_{10}$ & $\mathrm{SRI}+1.0 \% \mathrm{FeSO}_{4}+1.0 \% \mathrm{Na}_{2} \mathrm{SiO}_{3}$ & 109.47 & 20.07 & 112.4 & 5.44 \\
\hline & F test & $\mathrm{S}$ & $\mathrm{S}$ & $\mathrm{S}$ & $\mathrm{S}$ \\
\hline & SEm \pm & 1.02 & 0.47 & 1.84 & 0.21 \\
\hline & $\mathrm{CD}(\mathrm{P}=0.05)$ & 3.04 & 1.38 & 5.48 & 0.62 \\
\hline
\end{tabular}

\begin{tabular}{|c|c|c|c|c|c|}
\hline & & \multicolumn{3}{|c|}{ Table.2 Influence of planting system, foliar application of iron and silicon on yield attributes and yield of rice. } & \\
\hline & Treatment & No. of effective tillers/hill & Length of panicle $(\mathrm{cm})$ & No. of grains/panicle & Test weight (g) \\
\hline $\mathrm{T}_{1}$ & CTR + Control & 9.13 & 21.27 & 177.80 & 20.04 \\
\hline $\mathrm{T}_{2}$ & $\mathrm{CTR}+0.5 \% \mathrm{FeSO}_{4}$ & 10.07 & 21.75 & 182.47 & 20.42 \\
\hline $\mathrm{T}_{3}$ & $\mathrm{CTR}+1.0 \% \mathrm{FeSO}_{4}$ & 9.53 & 22.05 & 181.40 & 20.11 \\
\hline $\mathrm{T}_{4}$ & $\mathrm{CTR}+0.5 \% \mathrm{FeSO}_{4}+0.5 \% \mathrm{Na}_{2} \mathrm{SiO}_{3}$ & 10.20 & 22.41 & 263.77 & 20.22 \\
\hline $\mathrm{T}_{5}$ & $\mathrm{CTR}+1.0 \% \mathrm{FeSO}_{4}+1.0 \% \mathrm{Na}_{2} \mathrm{SiO}_{3}$ & 10.93 & 22.92 & 267.24 & 20.74 \\
\hline $\mathrm{T}_{6}$ & SRI + Control & 17.83 & 22.05 & 188.80 & 20.14 \\
\hline $\mathrm{T}_{7}$ & $\mathrm{SRI}+0.5 \% \mathrm{FeSO}_{4}$ & 18.00 & 22.23 & 206.73 & 20.19 \\
\hline $\mathrm{T}_{8}$ & $\mathrm{SRI}+1.0 \% \mathrm{FeSO}_{4}$ & 18.07 & 22.20 & 200.27 & 20.27 \\
\hline $\mathrm{T}_{9}$ & $\mathrm{SRI}+0.5 \% \mathrm{FeSO}_{4}+0.5 \% \mathrm{Na}_{2} \mathrm{SiO}_{3}$ & 18.47 & 23.46 & 264.33 & 20.52 \\
\hline \multirow[t]{4}{*}{$\mathrm{T}_{10}$} & $\mathrm{SRI}+1.0 \% \mathrm{FeSO}_{4}+1.0 \% \mathrm{Na}_{2} \mathrm{SiO}_{3}$ & 19.20 & 22.93 & 283.92 & 21.25 \\
\hline & F test & $\mathrm{S}$ & $\mathrm{S}$ & $\mathrm{S}$ & NS \\
\hline & SEm \pm & 0.40 & 0.38 & 7.49 & 0.31 \\
\hline & $\mathrm{CD}(\mathrm{P}=0.05)$ & 1.18 & 1.14 & 22.66 & - \\
\hline
\end{tabular}




\begin{tabular}{|c|c|c|c|c|}
\hline & \multicolumn{4}{|c|}{ Table.3 Influence of planting system, foliar application of iron and silicon on yield of rice } \\
\hline & Treatment & Grain yield (t/ha) & Straw yield (t/ha) & Harvest index (\%) \\
\hline $\mathrm{T}_{1}$ & CTR + Control & 5.15 & 8.90 & 36.67 \\
\hline $\mathrm{T}_{2}$ & $\mathrm{CTR}+0.5 \% \mathrm{FeSO}_{4}$ & 5.23 & 9.02 & 36.69 \\
\hline $\mathrm{T}_{3}$ & $\mathrm{CTR}+1.0 \% \mathrm{FeSO}_{4}$ & 5.39 & 8.98 & 37.52 \\
\hline $\mathrm{T}_{4}$ & $\mathrm{CTR}+0.5 \% \mathrm{FeSO}_{4}+0.5 \% \mathrm{Na}_{2} \mathrm{SiO}_{3}$ & 5.42 & 9.19 & 37.09 \\
\hline $\mathrm{T}_{5}$ & $\mathrm{CTR}+1.0 \% \mathrm{FeSO}_{4}+1.0 \% \mathrm{Na}_{2} \mathrm{SiO}_{3}$ & 5.83 & 9.16 & 38.88 \\
\hline $\mathrm{T}_{6}$ & SRI + Control & 5.30 & 9.01 & 37.05 \\
\hline $\mathrm{T}_{7}$ & $\mathrm{SRI}+0.5 \% \mathrm{FeSO}_{4}$ & 5.35 & 9.20 & 36.77 \\
\hline $\mathrm{T}_{8}$ & $\mathrm{SRI}+1.0 \% \mathrm{FeSO}_{4}$ & 5.46 & 9.17 & 37.30 \\
\hline $\mathrm{T}_{9}$ & $\mathrm{SRI}+0.5 \% \mathrm{FeSO}_{4}+0.5 \% \mathrm{Na}_{2} \mathrm{SiO}_{3}$ & 5.86 & 9.13 & 39.09 \\
\hline \multirow[t]{4}{*}{$\mathrm{T}_{10}$} & $\mathrm{SRI}+1.0 \% \mathrm{FeSO}_{4}+1.0 \% \mathrm{Na}_{2} \mathrm{SiO}_{3}$ & 6.08 & 9.31 & 39.50 \\
\hline & F test & $\mathrm{S}$ & S & S \\
\hline & $\mathrm{SEm} \pm$ & 0.09 & 0.05 & 0.39 \\
\hline & $\mathrm{CD}(\mathrm{P}=0.05)$ & 0.27 & 0.15 & 1.15 \\
\hline
\end{tabular}


Higher grain yield with SRI had more open architecture, with tillers spreading out more widely, covering more ground area and more erect leaves that avoided mutual shedding of leaves and these plants had higher LAI due to significant increase in leaf size and erect leaves in rice which might had increased the grain yield (Kumar et al, 2013). Positive effect of iron by foliar spray on grain yield might be due to increase in chlorophyll content of leaves lead to increased photosynthesis and resulted in more tillers, dry weight and LAI. Hence, more capture capture of solar radiation which resulted in higher grain yield (Das et al., 2016). silicon enhanced the sturdiness in plants and enhanced the photosynthetic activity, which helped in better assimilation of organic constituents (carbohydrates) which lead to increase the economic yield of rice crop (Anand et al., 2018).

The highest straw yield under SRI was due to adequate supply of nutrients which might contribute towards higher dry matter accumulation and better partitioning of photosynthate resulting in higher yield traits and ultimately the straw yield (Singh et al., 2015).Foliar application of iron may be attributed to increase in crop growth and photosynthates from source to sink. These results also confirm the findings of Sowmya et al., 2017; Shaygany et al., 2012.There was significant increase in straw yield with the silicon. This might be due to the role of silicon in improving the photosynthetic activity and accumulation in plant parts which reduced lodging and enhanced resistance against abiotic and biotic stress. All these factors might have resulted into higher straw yield. These results are in conformity with the findings of Patil et al., 2017 and Singh et al., 2007.

Maximum harvest index SRI promotes better aeration, more space and less competition, which may have enabled the plants to grow vigorously. Further, better partitioning of dry matter, which leads to increase in the number of effective tillers, number of grains per panicle and grain production (samant, 2017), ultimately resulting in enhanced harvest index. These results are in agreement with the findings of Krishna et al., 2008. Simultaneously, conventional system also exhibited acceptable harvest index values which might have been due to proper availability of nutrients in all the growth stages by inorganic sources that eventually lead to higher LAI, dry matter accumulation and higher productive tillers per unit area (Nayak and Biswal, 2018).foliar application of iron which might be due to better source to sink translocation of carbohydrates resulting higher grain yield and less straw (Singh and Singh., 2018). Similar findings were also made by Naik and Das. (2007). Silicon which was due to increase in grain yield rather than biomass (Lavinsky et al., 2016) (Table 2 and $3)$.

From the above results, following conclusions were observed during the research. SRI + $1.0 \% \mathrm{FeSO}_{4}+1.0 \% \mathrm{Na}_{2} \mathrm{SiO}_{3}$ was found to be best treatment for obtaining maximum number of tillers/hill (20.07), dry weight (112.4), effective tillers/hill (19.20), number of grains/panicle (283.92), grain yield (6.08 $\mathrm{t} / \mathrm{ha})$, straw yield $(9.31 \mathrm{t} / \mathrm{ha})$ and harvest index $(39.50 \%)$.

\section{References}

Abadia, J., Vazquez, S., Alvarez, R., Jendoubi, E.I., Abadia, A., Fernandez, A. and Millan, A.F. 2011. Towards a knowledge-based correction of iron chlorosis. Plant physiology and Biochemistry 49: 471-482.

Ali, N. and Izahar. T. 2017. Performance of SRI principles on growth, yield and profitability of rice (Oryza sativa L.). 
Journal of Pharmacognosy and Phytochemistry 6(5): 1355-1358.

Anand, L., Sreekanth, B. and Jyothula, D.P.B. 2018. Effect of foliar application of sodium silicate on yield and grain quality of rice. International Journal of Chemical Studies 6(6): 1711-1715.

Anwari, G., Moussa, A.A., Wahidi, A.B., Mandozai, A. Nasar, J. and Rahim, M.G.M. 2019. Effects of Planting Distance on Yield and Agromorphological Characteristics of Local Rice (Bara Variety) in Northeast Afghanistan. Current Agriculture Research Journal 7(3).

Das, L., Kumar, R., Kumar, V., Kumar, V. and Kumar, N. 2016. Effect of moisture regimes and levels of iron on growth and yield of rice under aerobic condition. The Bioscan 11(4): 24752479.

Esfahani, A. A., Pirdashti, H. and Niknejhad, Y. 2014. Effect of iron, zinc and silicon application on quantitative parameters of rice. Intl. J. Farm and Allied Sciences 3(5): 529-533.

Fallah, A. 2012. Silicon effect on lodging parameters of rice plants under hydroponics culture. International Journal of Agricultural Science 2(7): 630-634.

FAO. 2018. FAO STAT Production Statistics, Food and Agriculture Organization, Rome, Italy, December 12, 2018, pp 25-43.

Gee, G.W. and Baudev, J.W. 1986. Particle size analysis. Inmethods of soil analysis. Part 1, Physical and mineralogical method (A. Kluse Ed) pp. 404-408. Agronomy monogram No. 9, American Society of Agronomy, Madisom, w1.

Haldar, S., Honnaiah. and Govindaraj, G. 2012. System of Rice Intensification (SRI) method of rice cultivation in west Bengal. An Economic Analysis.
Selected Poster prepared for presentation at the International Association of Agricultural Economists (IAAE) Triennial Conference, Foz do Iguaçu, Brazil, 18-24.

IRRI (International Rice Research Institute). 2016. Silicon deficiency. Avaliable: http://irri.com (25 Dec 2016).

Jackson, M.L. 1973. Soil chemical analysis. Prentice Hall of India Private Limited, New Delhi, p. 498.

Jolley, V.D., Cook, K.A., Hansen, N.C., Stevens, W.B. 1996. Plant physiological responses for genotypic evaluation of iron efficiency in strategy I and strategy II plants. Journal of Plant Nutrition19: 1241-1255.

Krishna, A., Biradarpatil, N.P. and Channappagoudar, B.B. 2008. Influence of system of rice intensification (SRI) cultivation on seed yield and quality. Karnataka Journal of Agricultural Sciences 21(3): 369-372.

Kulhare, P.S., Tagore, G.S. and Sharma, G.D. 2017. Effect of foliar spray and sources of zinc on yield, zinc content and uptake by rice grown in vertisols of central India. International Journal of Chemical Studies 5(2): 35-38.

Kumar, D., Kumar, V., Singh, Y.V. and Raj, R. 2015. Effect of iron fertilization on dry matter production, yield and economics of aerobic rice. Indian Journal of Agronomy 60(4): 547-553.

Kumar, V., Kumar, D., Singh, Y.V., Raj, R. and Singh, N. 2018. Effect of iron nutrition on plant growth and yield of aerobic rice. International Journal of Chemical Studies 6(4): 999-1004.

Lavinsky, A.O., Detmann, K.C., Reis, J.V., Avila, R.T., Sanglard, M.L., Pereira, L.F., Sanglard, L.M.V.P., Rodrigues, F.A, Araujo, W.L. and Matta, F.M. 2016. Silicon improves rice grain yields and photosynthesis specifically when supplied during the reproductive 
growth stage. Journal of Plant Physiology 206: 125-132.

Mahajan, G and Khurana, M.P.S. 2014. Enhancing productivity of dry seeded rice in North-West India through foliar application of Iron and Potassium Nitrate. VEGETOS, 27(2): 301-306.

Mali, M. and Aery, N.C. 2008. Silicon effects on nodule growth, dry matter production and mineral nutrition of cowpea (Vigna unguiculate). Journal of Plant Nutrition Soil Science 171: 83540.

Mcginnity, P. 2015. Silicon and its role in crop production. Available: http://www.planttuff.com/pdf (25 Dec. 2016).

Mehta, D.S., Dhillon, B.S. and Dhillon, S.S. 2019. Performance of Basmati Rice (Oryza sativa L.) under Different Transplanting Dates and Plant Spacings in South West Punjab. Int. J. Cur. Microbiol. App. Sci. 8(7): 2016-2020.

Mishra, B. N., and Mishra. P.K. 2003. Direct and residual effect of levels of zinc and iron and their mode of application on productivity of rice-wheat cropping system. Annals of Agricultural Research. 24:221-226.

Mohammad, U., wayayok, A. and Abdan, K. 2016. System of Rice Intensification an alternative to increase rice yield. Scientific Times Journal of Agriculture 1(1): 1001-1005.

Munir, M. C. C., Carlos, G.F., Heilo. and Juliano, C.C. 2003. Nitrogen and silicon fertilization of upland rice. Scientia Agricola, 60(4): 1-10.

Naik, S.K. and Das, D.K. 2007. Effect of split application of iron and zinc on yield of rice in an inceptisols. Archives of Agronomy and Soil Science 53(3): 305313.

Nayak, A. and Biswal, S. 2018. Performance of rice in modified conventional system over system of rice intensification
(SRI). International Journal of Current Microbiology and Applied Sciences6: 2163-2168

Ninad, T.A., Bahadur, M.M., Hasan, M.A., Alam, M.M. and Rana, M.S. 2017. Effect of spacing and seedling per hill on the performance of rice var. BRRI dhan 48. Bangladesh agronomy journal 20(2): 17-26.

Olsen, S.R., Cole, C.V., Watanable, F.S. and Dean, L.A. 1954. Estimation of available phosphorus in soil by extraction with sodium bicarbonate. U.S. Department of Agriculture Circular 930, U.S. Govt. Printing Office, Washington DC.

Pal, S., Datta, S.P., Rattan, R.K. and Singh, A.K. 2008. Diagnosis and amelioration of iron deficiency under aerobic rice. Journal of Plant Nutrition 31: 919-940.

Patil, A.A., Durgude, A.G., Pharande, A.L., Kadlag, A.D. and Nimbalkar, C.A. 2017. Effect of calcium silicate as a silicon source on growth and yield of rice plants. International Journal of Chemical Studies 5(6): 545-549.

Prakash, N.B., Chandrashekar, N., Mahendra, C., Patil, S.U., Thippeshappa, G.N. and Laane, H.M. 2011. Effect of foliar spray of silicic acid on growth and yield parameters of wetland rice in hilly soils of Karnataka. Journal of Plant Nutrition 34(12): 1883-1893.

Rao, G. and Susmitha, P. 2017. Silicon uptake, transportation and accumulation in Rice. Journal of Pharmacognosy and Phytochemistry 6(6): 290-293.

Rattan, R.K., Datta, S.P. and Katyal, J.C. 2008. Micronutrient management: research achievements and future challenges. Indian Journal of Fertilizers 4(12): 103-106.

Reddy, R.J. and Shenoy, N.S. 2013. comparative economic analysis of Traditional and System of Rice 
Intensification (SRI) rice cultivation practices. International Journal of Scientific and Research 3(10): 22503153.

Saju, S.M., Tavaprakash, N., Sakthivel, N. and Malathi, P. Influence of highdensity planting on growth and yield of rice (Oryza sativa L.) under modified system of rice intensification. Journal of Pharmacognosy and Phytochemistry 8(3): 3376-3380.

Samant, T.K., 2017. Promotion of system of rice intensification method in midcentral table land zone of Odisha. International journal of sciences, Environment 6(4): 2276-2282.

Savant, N.K., Snyder, G.H. and Datnoff L.E. 1997. Silicon management and sustainable rice production. Advances in Agronomy 58: 1245-1252.

Shashidhar, H.E., Chandrashekar, N., Mahendra, A.C., Naryanaswamy, C., and Prakash, N.B. 2008. Calcium silicate as silicon source and its interaction with nitrogen in aerobic rice. Silicon in Agriculture: $4^{\text {th }}$ International Conference.

Shaygany, J., Peivandy, N. and Ghasemi, S. 2012. Increased yield of direct seeded rice by foliar fertilization through multi-component fertilizers. Archives of Agronomy and Soil Science 58(10): 1091-1098.

Singh, A.K. and Singh, V. 2018. Effect of foliar application of iron, zinc and age of seedlings on age of seedlings on growth and yield of rice. International Journal of Current Microbiology and Applied Sciences 7(8): 1062-1068.
Singh, C.S., Singh, M, Singh, S.K., Singh, A.K. and Singh, A.K.R. 2015. Growth and yield response of rice cultivars under system of rice intensification and conventional method of rice production system. The Ecoscan 9(3\&4): 10771081.

Singh, K. Singh, K.K. and Singh, Y. 2007. Effect of silicon carriers and time of application on rice productivity in a rice-wheat cropping sequence. IRRN 32(1): 30-31.

Sowmya, B., Vani, K.P., Babu, P.S., Rao, V.P. and Surekha, K. 2017. Impact of iron nutrition on yield and economics of aerobic rice cultivars. Journal of Pharmacogency and Phytochemistry 6(5): 1096-1100.

Subbiah B and Asija G L 1956. A rapid procedure for estimation of available nitrogen in soils. Curr Sci 25(8): 1-6.

Sudha, S. and Stalin, P. 2015. Effect of zinc on yield, quality and grain zinc content of rice genotypes. International Journal of Farm Sciences 5(3): 17-27.

Walkley A and Black I A, 1934. An examination of degtjareff method for determining soil organic matter and a proposed modification of chromic acid titration method. Soil Sci 37: 29-37.

Zheng, J, L.U., Jiang, X.L, Tang, Y.L. 2004. The system of rice intensification (SRI) for super high yields of rice in Sichuan Basin. In: T. Fisher (Ed.), New Directions for a Diverse Planet: Proceedings for the $4^{\text {th }}$ International Crop Science Congress September, Brisbane, Australia.

\section{How to cite this article:}

Gangadi Kalyan Reddy, Umesha, C. and Thomas Abraham. 2020. Effect of Planting Systems and Foliar Application of Iron and Silicon on Growth and Yield of Rice (Oryza sativa L.) Int.J.Curr.Microbiol.App.Sci. 9(11): 532-541. doi: https://doi.org/10.20546/ijcmas.2020.911.065 